\title{
Oribatid mites (Acari, Oribatida) of pine and cypress litter in selected habitats of Sicily (Italy)
}

\author{
STANISŁAW SENICZAK ${ }^{1}$ and ANNA SENICZAK ${ }^{2}$ \\ ${ }^{1}$ Department of Zoology, Kazimierz Wielki University, Ossolińskich Av. 12, 85-092 Bydgoszcz, Poland \\ ${ }^{2}$ Department of Ecology, University of Technology and Life Sciences, Kordeckiego 20, \\ 85-225 Bydgoszcz, Poland \\ Corresponding author: Stanisław Seniczak, e-mail: stseni@ukw.edu.pl
}

(Received on 13 January 2012; Accepted on 17 September 2013)

\begin{abstract}
Oribatid mites live in the soil or plant matter and usually feed on living and dead plant or fungal material, lichens, carrion, or some species are rarely predatory. Oribatid communities were investigated in litter under pine and cypress trees in selected locations in Sicily: Etna slopes (near Rifugio Sapienza and near Castiglione di Sicily), coastal town Giardini Naxos, Archaeological Museum in Agrigento, and Archaeological Park in Sagesta. The most abundant and diverse oribatid mites lived in cypress litter in Agrigento and on Etna slope. The lowest numbers of individuals and species were recorded in pine litter in Agrigento. In the oribatid mite communities, only 1-3 species were abundant, so the values of Shannon $H^{\prime}$ index, and Pielou $E_{\text {Pielou }}$ and Hurlbert $E_{\text {Hurbert }}$ evenness indices were rather low. Their values were the highest in pine litter near Rifugio Sapienza, located nearest to the crater of Etna, while the lowest in pine litter in Agrigento. The former habitat was rich in oribatid mites and species, with a large participation of small species, like Suctobelbella subcornigera, Brachychthonius impressus, and Liochthonius simplex, which made up nearly $63 \%$ of the total number of oribatid mites within that habitat. In other habitats, usually Oribatula propinqua dominated, but in pine and cypress litter in Giardini Naxos, Oppiella nova and Ramusella clavipectinata were the most abundant, respectively. Among oribatid mites, adults usually dominated, but Adrodamaeus femoratus, Aphelacarus acarinus, Brachychthonius impressus, Liochthonius simplex, Cosmochthonius reticulatus, Metabelba pulverulenta and Pilogalumna crassiclava were rich in juveniles.
\end{abstract}

Keywords: Sicily, Mount Etna, habitats, oribatid mites, dominance and age structure

\section{INTRODUCTION}

Oribatid mites are important parts of ecosystems. They live mainly in the soil or plant matter and usually feed on living or dead plant or fungal material, lichens, carrion, and some species can be also predatory as egg-eaters. Hot and dry Sicilian summers limit the development of most oribatid species, which multiply mainly in winter (Stamou \& Sgardelis 1989). However, some species are adapted to Medi- 
terranean conditions and achieve in summer a high density and dominance index. Therefore, these habitats are interesting for research on oribatid mite communities, and their age structure. The oribatid mites of Sicily were earlier investigated mainly in zoogeographical and faunistic aspects (BERLESE 1883, 1910; ArCIDIACONO 1975; BERNINI et al. 1995).

In this paper we report on soil oribatid mite communities of litter under pine and cypress trees in selected parts of Sicily, with special attention to the age structure of some populations, which is rarely investigated in ecological papers.

\section{STUDY AREA}

Sicily in an interesting island to study because of Mount Etna - the highest, largest, and most active volcano in Europe. It reaches about $3330 \mathrm{~m}$ a.s.1., so during eruptions the emitted ashes and gases pollute a large area. Since the 5th century, 80 larger eruptions have been recorded, with the largest one in 1669, which damaged and covered by lava and ash almost the whole Catania. The last eruption of the volcano occurred on 13 January 2011.

Lower parts of Sicily are covered with typical Mediterranean vegetation. In coastal areas, with touristic cities and villages, typical plants include bitter orange (Citrus sp.), lemon (Citrus limon Burm.), cypress (Cupressus sp.), fig (Ficus carica L.), and jacaranda (Jacaranda sp.) trees. The lower slopes of Mount Etna offer fertile soils, so a dense human population lives there, despite the potential danger from volcano eruptions. Arable fields, vineyards, olive-tree (Olea europaea L.), orange, and other orchards cover the Etna slopes up to 800-900 m a.s.l. Higher parts, up to $3000 \mathrm{~m}$ a.s.1., are dominated by evergreen holm oak (Quercus ilex L.), beech (Fagus sylvatica L.), and chestnut (Castanea sativa Miller) forests, while the uppermost parts are covered by congealed lava and patches of grasses and herbs.

The Sicilian climate depends on altitude. The coastal parts represent a typical Mediterranean climate, with hot and dry summer (June-September, mean daily temperature $27-31^{\circ} \mathrm{C}$, total precipitation about $85 \mathrm{~mm}$ ) but mild and wet winter (October-May, mean daily temperature $15-24^{\circ} \mathrm{C}$, total precipitation about $570 \mathrm{~mm}$ ), with about 2500 sunny hours per year, while the climate of mountains is more continental.

\section{MATERIAL AND METHODS}

Samples of litter $\left(500 \mathrm{~cm}^{3}\right.$ each) under pine trees (Pinus heldreichii H. Christ) and cypress trees (Cupressus sp.) were taken on 25-31 May of 2009, in 3 replicates, from the following locations and habitats:

(a) slopes of Etna - pine litter on the southern slope of Etna, near Rifugio Sapienza $\left(37^{\circ} 41^{\prime} \mathrm{N}, 15^{\circ} 00^{\prime} \mathrm{E} ; 1947 \mathrm{~m}\right.$ a.s.1., slightly above the forest line), and cypress litter on the eastern slope of Etna, in Ravine Alacantara near Castiglione di Sicily $\left(37^{\circ} 51^{\prime} \mathrm{N}, 15^{\circ} 12^{\prime} \mathrm{E}, 143 \mathrm{~m}\right.$ a.s.1.), between Rifugio Sapienza and Giardini Naxos;

(b) coastal town Giardini Naxos $\left(37^{\circ} 49^{\prime} \mathrm{N}, 15^{\circ} 15^{\prime} \mathrm{E} ; 28 \mathrm{~m}\right.$ a.s.1.);

(c) Archaeological Museum in Agrigento (37 $18^{\prime} \mathrm{N}, 13^{\circ} 32^{\prime} \mathrm{E}, 234 \mathrm{~m}$ a.s.1.);

(d) Archaeological Park in Sagesta (37 $56^{\prime} \mathrm{N}, 12^{\circ} 50^{\prime} \mathrm{E}, 283 \mathrm{~m}$ a.s.1.). 
The mites were extracted in Tullgren funnels, conserved, and determined to species or genus level, including the juveniles. Names of oribatid species follow SuBías (2004) and partly WeIGMANN (2006). Populations of oribatid species (18 139 mites in total) were characterized with abundance $(A)$ and dominance $(D)$ indices (ODum 1971), while mite communities were compared with Shannon indices $H^{\prime}, H_{\min }$, and $H_{\max }$ as well as Pielou $\left(E_{\text {Pielou }}\right)$ and Hurlbert $\left(E_{\text {Hurlbert }}\right)$ evenness indices (BEISEL et al. 2003).

\section{RESULTS}

The most abundant and diverse oribatid mite communities lived in cypress litter in Agrigento and on Etna slope, while the lowest numbers of individuals and species were recorded in pine litter in Agrigento (Table 1). Generally, cypress litter was richer in mite individuals than pine litter. In the oribatid mite communities, 1-3 species were abundant, so the Shannon index $H^{\prime}$ and Pielou $E_{\text {Pielou }}$ and Hurlbert $E_{\text {Hurlbert }}$ evenness indices were rather low, with the highest value in pine litter on Etna slope, and the lowest value in pine litter in Agrigento.

Table 1. Mean density (individuals per sample, i.e. $500 \mathrm{~cm}^{3}, n=3$ ), number of species, and diversity indices (Shannon $H^{\prime}, H_{\min }, H_{\max }$, Pielou and Hurlbert evenness) of oribatid mite communities in selected habitats of Sicily. Pine $=$ pine litter; Cyp. $=$ cypress litter

\begin{tabular}{lrrrrrrrr}
\hline \multirow{2}{*}{ Parameter } & \multicolumn{2}{c}{ Etna slopes } & \multicolumn{2}{c}{ Giardini Naxos } & \multicolumn{2}{c}{ Agrigento } & \multicolumn{2}{c}{ Segesta } \\
& \multicolumn{1}{c}{ Pine } & \multicolumn{1}{c}{ Cyp. } & \multicolumn{1}{c}{ Pine } & Cyp. & Pine & Cyp. & Pine & Cyp. \\
\hline Mean density of Oribatida & 716.0 & 1418.7 & 818.7 & 694.3 & 503.0 & 1508.0 & 316.0 & 768.5 \\
Mean density of juveniles & 304.3 & 610.0 & 163.7 & 196.7 & 205.0 & 849.7 & 42.0 & 327.0 \\
Number of species & 19 & 31 & 28 & 22 & 9 & 28 & 22 & 18 \\
Shannon index $H$ & 2.09 & 1.93 & 1.71 & 1.74 & 0.69 & 1.05 & 1.75 & 1.56 \\
Shannon index $H_{\min }$ & 0.19 & 0.18 & 0.26 & 0.22 & 0.11 & 0.15 & 0.45 & 0.16 \\
Shannon index $H_{\max }$ & 2.94 & 3.43 & 3.33 & 3.09 & 2.20 & 3.33 & 3.09 & 2.89 \\
Pielou evenness $E_{\text {Pielou }}$ & 0.71 & 0.58 & 0,51 & 0.56 & 0.31 & 0.32 & 0.57 & 0.64 \\
Hurlbert evenness $E_{\text {Hurbert }}$ & 0.69 & 0.54 & 0.47 & 0.53 & 0.28 & 0.28 & 0.49 & 0.55 \\
\hline
\end{tabular}

Pine litter near Rifugio Sapienza, located nearest to the crater of Etna, was rich in oribatid mites and species. In this mite community, small species were abundant, like Suctobelbella subcornigera (Forsslund, 1941), Brachychthonius impressus Moritz, 1976, and Liochthonius simplex (Forsslund, 1942), which jointly made up nearly $63 \%$ of all oribatid mites (Table 2). Cypress litter near Castiglione di Sicilia was much richer in oribatid mites and species than pine litter near Rifugio Sapienza. In the former mite community, the most abundant was the medium-sized species Oribatula propinqua (Oudemans, 1900), which accounted for nearly $62 \%$ of total oribatid mites, while small mite species were not abundant there. 
Table 2. Characteristics of oribatid species in selected habitats of Sicily: abundance ( $A=$ individuals per sample, i.e. $\left.500 \mathrm{~cm}^{3}, n=3\right)$ and dominance $(D=\%$ of the total number of oribatid mites in the mean sample). Pine = pine litter; Cyp. $=$ cypress litter. Species with maximum $A \leq 10$ are listed below the table

\begin{tabular}{|c|c|c|c|c|c|c|c|c|c|}
\hline \multirow{2}{*}{ Species name } & & \multicolumn{2}{|c|}{ Etna slopes } & \multicolumn{2}{|c|}{ Giardini Naxos } & \multicolumn{2}{|c|}{ Agrigento } & \multicolumn{2}{|c|}{ Segesta } \\
\hline & & Pine & Сур. & Pine & Сyp. & Pine & Сyp. & Pine & Cyp. \\
\hline \multirow{2}{*}{$\begin{array}{l}\text { Adrodamaeus femoratus } \\
\text { (C. L. Koch, 1839) }\end{array}$} & $A$ & 1.0 & 84.3 & 1.7 & 15.7 & 0 & 249.0 & 9.5 & 37.0 \\
\hline & $D$ & 0.1 & 5.9 & 0.2 & 2.3 & 0 & 16.5 & 3.0 & 4.8 \\
\hline \multirow{2}{*}{$\begin{array}{l}\text { Aphelacarus acarinus } \\
\text { (Berlese, 1910) }\end{array}$} & $A$ & 0 & 0 & 4.7 & 0.3 & 30.0 & 57.0 & 22.5 & 0 \\
\hline & $D$ & 0 & 0 & 0.6 & 0.1 & 5.9 & 3.8 & 7.1 & 0 \\
\hline \multirow{2}{*}{$\begin{array}{l}\text { Brachychthonius } \\
\text { impressus Moritz, } 1976\end{array}$} & $A$ & 156.3 & 1.3 & 29.3 & 1.7 & 0 & 7.0 & 0 & 3.0 \\
\hline & $D$ & 21.8 & 0.1 & 3.6 & 0.2 & 0 & 0.5 & 0 & 0.4 \\
\hline \multirow{2}{*}{$\begin{array}{l}\text { Cosmochthonius } \\
\text { reticulatus Grandjean, } \\
1947\end{array}$} & $A$ & 0.7 & 24.0 & 12.0 & 42.3 & 5.0 & 6.7 & 3.5 & 56.0 \\
\hline & $D$ & 0.1 & 1.7 & 1.5 & 6.1 & 1.0 & 0.4 & 1.1 & 7.3 \\
\hline \multirow{2}{*}{$\begin{array}{l}\text { Haplochthonius simplex } \\
\text { (Willmann, 1930) }\end{array}$} & $A$ & 2.0 & 10.0 & 5.0 & 94.7 & 13.0 & 57.7 & 1.0 & 183.0 \\
\hline & $D$ & 0.3 & 0.7 & 0.6 & 13.6 & 2.6 & 3.8 & 0.3 & 23.8 \\
\hline \multirow{2}{*}{$\begin{array}{l}\text { Licnodamaeus } \\
\text { costula Grandjean, } 1931\end{array}$} & $A$ & 0 & 60.7 & 0 & 0 & 0 & 4.3 & 15.5 & 2.0 \\
\hline & $D$ & 0 & 4.3 & 0 & 0 & 0 & 0.3 & 4.9 & 0.3 \\
\hline \multirow{2}{*}{$\begin{array}{l}\text { Liochthonius simplex } \\
\text { (Forsslund, 1942) }\end{array}$} & $A$ & 109.3 & 0 & 14.0 & 0 & 0 & 0 & 0 & 0 \\
\hline & $D$ & 15.3 & 0 & 1.7 & 0 & 0 & 0 & 0 & 0 \\
\hline \multirow{2}{*}{$\begin{array}{l}\text { Metabelba pulverulenta } \\
\text { (C. L. Koch, 1839) }\end{array}$} & $A$ & 0 & 0.3 & 0 & 0 & 0 & 0 & 14.6 & 1.0 \\
\hline & $D$ & 0 & $<0.1$ & 0 & 0 & 0 & 0 & 4.6 & 0.1 \\
\hline \multirow{2}{*}{$\begin{array}{l}\text { Oppiella nova } \\
\text { (Oudemans, 1902) }\end{array}$} & $A$ & 23.0 & 1.3 & 383.0 & 0.3 & 0 & 1.0 & 0 & 0 \\
\hline & $D$ & 3.2 & 0.1 & 46.8 & 0.1 & 0 & 0.1 & 0 & 0 \\
\hline \multirow{2}{*}{$\begin{array}{l}\text { Oribatula propinqua } \\
\text { (Oudemans, 1900) }\end{array}$} & $A$ & 87.3 & 879.0 & 36.0 & 101.0 & 416.0 & 1076.3 & 159.5 & 389.5 \\
\hline & $D$ & 12.2 & 61.9 & 4.4 & 14.6 & 82.7 & 71.3 & 50.5 & 50.7 \\
\hline \multirow{2}{*}{$\begin{array}{l}\text { Pilogalumna crassiclava } \\
\text { (Berlese, 1914) }\end{array}$} & $A$ & 60.7 & 15.00 & 99.3 & 70.3 & 0 & 6.3 & 0 & 49.5 \\
\hline & $D$ & 8.5 & 1.1 & 12.1 & 10.1 & 0 & 0.4 & 0 & 6.4 \\
\hline \multirow{2}{*}{$\begin{array}{l}\text { Punctoribates punctum } \\
\text { (C. L. Koch, 1839) }\end{array}$} & $A$ & 0 & 0 & 1.3 & 0 & $<0.1$ & 1.3 & 54.5 & 5.0 \\
\hline & $D$ & 0 & 0 & 0.2 & 0 & 0.1 & 0.1 & 17.3 & 0.7 \\
\hline \multirow{2}{*}{$\begin{array}{l}\text { Ramusella clavipectinata } \\
\text { (Michael, 1885) }\end{array}$} & $A$ & 10.0 & 0 & 0.3 & 320.3 & 1.0 & 0.3 & 0 & 2.5 \\
\hline & $D$ & 1.4 & 0 & $<0.1$ & 46.1 & 0.2 & $<0.1$ & 0 & 0.3 \\
\hline \multirow{2}{*}{$\begin{array}{l}\text { Scheloribates laevigatus } \\
\text { (C. L. Koch, 1835) }\end{array}$} & $A$ & 0.7 & 98.7 & 8.3 & 0.7 & 0 & 0 & 0.5 & 0 \\
\hline & $D$ & 0.1 & 6.9 & 1.0 & 0.1 & 0 & 0 & 0.2 & 0 \\
\hline \multirow{2}{*}{$\begin{array}{l}\text { Scheloribates pallidulus } \\
\text { (C. L. Koch, 1841) }\end{array}$} & $A$ & 0 & 126.7 & 188.7 & 0 & 0 & 0.3 & 0 & 0 \\
\hline & $D$ & 0 & 8.9 & 23.1 & 0 & 0 & $<0.1$ & 0 & 0 \\
\hline \multirow{2}{*}{$\begin{array}{l}\text { Suctobelbella } \\
\text { subcornigera (Forsslund, } \\
\text { 1941) }\end{array}$} & $A$ & 184.0 & 1.7 & 1.3 & 0.3 & 0 & 0 & 0 & 0 \\
\hline & $D$ & 25.7 & 0.1 & 0.2 & 0.1 & 0 & 0 & 0 & 0 \\
\hline \multirow{2}{*}{$\begin{array}{l}\text { Tectocepheus velatus } \\
\text { (Michael 1880) }\end{array}$} & $A$ & 6.0 & 56.0 & 1.0 & 7.3 & 1.0 & 0 & 1.0 & 1.0 \\
\hline & $D$ & 0.8 & 3.9 & 0.1 & 1.1 & 0.2 & 0 & 0.3 & 0.1 \\
\hline
\end{tabular}


Etna slope, pine litter: Camisia segnis (Hermann, 1804); Damaeus sp. 1; Dissorhina ornata (Oudemans, 1900); Lohmannia paradoxa (Haller, 1884); Microtritia minima (Berlese, 1904); Oppiella translamellata (Willmann, 1923); Ramusella sp. 1; Oribatida juv.

Etna slope, cypress litter: Eueremaeus oblongus (C. L. Koch, 1835); Eulohmannia ribagai (Berlese, 1910); Eupelops sp. 1; Euzetes globulus (Nicolet, 1855); Fosseremus laciniatus (Berlese, 1905); Liochthonius sp. 1; Malaconothrus sp. 1; Nothrus anauniensis Canestrini et Fanzago, 1876; Oppia denticulata (G. Canestrini et R. Canestrini, 1882); Oppiella sp. 1; Oribatella superbula (Berlese, 1904); Phthiracarus sp. 1; Platynothrus peltifer (C. L. Koch, 1839); Protoribates sp. 1; Rhysotritia duplicata (Grandjean, 1953); Sphaerochthonius splendidus (Berlese, 1904); Tectocepheus velatus (Michael, 1880); Trimalaconothrus sp. 1; Oribatida juv.

Giardini Naxos, pine litter: Aphelacarus acarinus (Berlese, 1910); Damaeus sp. 1; Dorycranosus acutus (Pschorn-Walcher, 1951); Eueremaeus oblongus; Eupelops acromios (Hermann, 1804); Galumna sp. 1; Gustavia microcephala (Nicolet, 1855); Liacarus coracinus (C. L. Koch, 1841); Licnodamaeus costula Grandjean, 1931; Oppiella sp. 2; Oribatula sp. 1; Pasallozetes africanus Grandjean, 1932; Sphaerochthonius splendidus.

Giardini Naxos, cypress litter: Achipteria nitens (Nicolet, 1855); Aphelacarus acarinus; Dorycranosus acutus; Eupelops acromios; Eupelops sp.1; Liacarus coracinus; Oppiella sp. 2, Oribatula excavata (Berlese, 1916); Scheloribates latipes (C. L. Koch, 1844); Sphaerochthonius splendidus; Oribatida juv.

Agrigento, pine litter: Dorycranosus acutus; Tectocepheus velatus; Oribatida juv.

Agrigento, cypress litter: Achipteria nitens; Aphelacarus acarinus; Chamobates sp. 1; Damaeus sp. 1; Eueremaeus oblongus; Eupelops acromios; Galumna sp. 1; Jacotella reticulata Ruiz, Kahwash et Subías, 1990; Liacarus coracinus; Oribatula excavata; Passalozetes africanus; Ramusella sp. 1; Scheloribates latipes; Sphaerochthonius splendidus; Trimalaconothrus sp. 1; Xenillus tegeocranus (Hermann, 1804); Oribatida juv.

Sagesta, pine litter: Aphelacarus acarinus; Camisia segnis; Chamobates sp.1; Damaeus sp. 1; Dorycranosus acutus; Eueremaeus oblongus; Jacotella reticulata; Kunstidamaeus tecticola (Michael, 1888); Oppiella sp. 2; Passalozetes africanus; Scheloribates initialis (Berlese, 1908), Sphaerochthonius splendidus.

Sagesta, cypress litter: Aphelacarus acarinus; Nothrus anauniensis; Oppia sp. 1; Oppiella sp. 2; Oribatella quadricornuta (Michael, 1882); Sphaerochthonius splendidus; Zetorchestes falzonii Coggi, 1898; Oribatida juv.

In the coastal town Giardini Naxos, pine litter was richer in oribatid mites and species than cypress litter, and in both habitats small oppioid species dominated: Oppiella nova (Oudemans, 1902) and Ramusella clavipectinata (Michael, 1885), respectively. In contrast, in pine and cypress litter in Agrigento and Segesta, Oribatula propinqua highly dominated, and cypress litter was richer in individuals than pine litter, especially in Agrigento. In the investigated habitats, relatively abundant were Scheloribates latipes (C. L. Koch, 1835) (pine litter, Giardini Naxos), Haplochthonius simplex (Willmann, 1930) (cypress litter, Giardini Naxos and Segesta), Punctoribates punctum (C. L. Koch, 1839) (pine litter, Segesta), and Adrodamaeus femoratus (C. L. Koch, 1839) (cypress litter, Agrigento).

In oribatid mite communities usually the adults dominated, except for cypress litter in Agrigento, where the juveniles were slightly more abundant than the adults. The age structure of species depended on their biology and kind of litter (Table 3). Several species, like Adrodamaeus femoratus, Aphelacarus acarinus (Berlese, 1910), Brachychthonius impressus, Liochthonius simplex, Cosmochthonius reticulatus Grandjean, 1947, Metabelba pulverulenta (C. L. Koch, 1839), and P. crassicla$v a$ (Berlese, 1914), were rich in juveniles, while Haplochthonius simplex, Oppiella 
Table 3. Mean age structure of chosen oribatid species in selected habitats of Sicily

\begin{tabular}{llrrr}
\hline Species name & Habitat & Juveniles & Adults & Total \\
\hline Aphelacarus acarinus & Agrigento, cypress litter & 38.3 & 18.7 & 57.0 \\
Adrodamaeus femoratus & Segesta, pine litter & 148.7 & 100.3 & 249.0 \\
& Etna slope, cypress litter & 58.7 & 25.6 & 84.3 \\
Brachychthonius impresus & Etna slope, pine litter & 119.6 & 36.7 & 156.3 \\
& Gardini Naxos, pine litter & 17.7 & 11.6 & 29.3 \\
Cosmochthonius reticulatus & Sagesta, cypress litter & 31.0 & 25.0 & 56.0 \\
& Gardini Naxos, cypress & 38.6 & 3.7 & 42.3 \\
& litter & & & \\
Haplochthonius simplex & Etna slope, cypress litter & 11.7 & 12.3 & 24.0 \\
& Sagesta, cypress litter & 2.5 & 180.5 & 183.0 \\
& Gardini Naxos, cypress & 7.7 & 87.0 & 94.7 \\
Liochthonius simplex & litter & & & \\
Metabelba pulverulenta & Agrigento, cypress litter & 1.0 & 56.7 & 57.7 \\
Oppiella nova & Etna slope, pine litter & 98.7 & 10.6 & 109.3 \\
Oribatula propinqua & Erice, cypress litter & 36.0 & 23.0 & 59.0 \\
& Gardini Naxos, pine litter & 71.0 & 312.0 & 383.0 \\
& Agrigento, cypress litter & 640.3 & 436.0 & 1076.3 \\
Pilogalumna crassiclava & Etna slope, cypress litter & 451.7 & 427.3 & 879.6 \\
& Agrigento, pine litter & 153.0 & 263.0 & 416.0 \\
Scheloribates latipes & Sagesta, cypress litter & 219.0 & 162.0 & 381.0 \\
S. laevigatus & Gardini Naxos, pine litter & 45.0 & 54.3 & 99.3 \\
Tectocepheus velatus & Gardini Naxos, cypress & 51.7 & 18.7 & 70.3 \\
& litter & & & \\
& Gardini Naxos, pine litter & 1.0 & 187.7 & 188.7 \\
& Etna slope, cypress litter & 19.0 & 79.7 & 98.7 \\
& Etna slope, cypress litter & 16.0 & 110.7 & 126.7 \\
& Etna slope, cypress litter & 19.0 & 37.0 & 56.0 \\
& Etna slope, pine litter & 4.0 & 2.0 & 6.0 \\
\hline & & & &
\end{tabular}

nova, Scheloribates laevigatus, and $S$. latipes were represented mainly by adults. The age structure of Oribatula propinqua depended on locality: in pine litter in Agrigento the adults dominated, while in other habitats the juveniles were more abundant.

\section{DISCUSSION}

The investigated oribatid mite communities of Sicily are under a strong influence of the activity of Mount Etna, especially those located on higher slopes of this volcano. During volcano eruption a lot of ashes and gases are emitted, and they are finally partly deposited with rainfall also in leaf litter and affect the soil oribatid mites. The pine litter near Rifugio Sapienza, located nearest to the crater of volcano Etna, contains a lot of dark ash, but in spite of that it was rich in oribatid mites and species, 
which are probably adapted to volcanic activity. This mite community was dominated by small species (like Suctobelbella subcornigera) and species of the genus Brachychthonius, with a short life cycle (HÅGVAR et al. 2009), and they are probably able to multiply quickly. The species of Brachychthoniidae are regarded as first colonizers on mine dumps (SKubAŁA 2000) and in mine sedimentation tanks (SKubAŁA 2002) in the post-industrial landscape of Silesia (SW Poland). These mites are also abundant in the first stage of primary succession of oribatid mites near the foreland of the Norwegian glacier in Finse, southern Norway (HÅgVAR et al. 2009).

In cypress litter near Castiglione di Sicilia, situated between Rifugio Sapienza and coastal Giardini Naxos, Suctobelbella subcornigera and Brachychthonius spp. were not abundant, but the larger species Oribatula propinqua dominated, which was also abundant in most of the other studied habitats and in pine and cypress litter in southern Italy (SENICZAK \& SENICZAK 2012). Species of the family Oribatulidae are common in the Mediterranean region. They were the most diverse on Canary Islands, Spain (MorAZA \& PEÑA 2005a, b), and abundant in grass and cypress litter in Andalusia, Spain (SEniczak \& Seniczak 2010), moss patches in Korčula, Croatia (SeniczaK et al. 2012), and in steppe vegetation of Cape Tarkhankut, Crimea, Ukraine (SENICZAK et al. 2009, 2011).

Oribatid mites in the investigated habitats of Sicily are more abundant and richer in species than those in Andalusia (SENICZAK \& SENiczak 2010), but are comparable with those found in yew and cypress litter in Caserta, Italy (SENICZAK \& SENICZAK 2012), and in moss patches at the forest floor in Korčula, Croatia (SENICZAK et al. 2012), probably due to higher fertility of soils in those habitats. However, high dominance indices of these species indicate in the light of Thienemann's principles (1939) a rather low soil fertility. Several species were rich in juveniles, which demonstrated that spring is a good season for their development. Most species listed in Table 2 were recorded in Sicily by BERNINI et al. (1995), except for Lohmannia paradoxa (Haller, 1884), which is a new species for Sicily and Italy.

\section{CONCLUSIONS}

1. The most abundant oribatid mites and richest in species lived in cypress litter in the Archaeological Museum in Agrigento and on Etna slopes, while the poorest in individuals and species was pine litter in the Archaeological Museum in Agrigento. In oribatid mite communities, 1-3 species were abundant, so the Shannon index $H^{\prime}$ and Pielou and Hurlbert evenness indices $\left(E_{\text {Pielou }}\right.$ and $\left.E_{\text {Hurlbert }}\right)$ were generally low.

2. The pine litter located nearest to the crater of Etna was rich in oribatid mite individuals and species, especially in small mites (Suctobelbella subcornigera, Brachychthonius impressus, Liochthonius simplex), with a rather short life cycle. Other habitats were usually dominated by a medium-sized mite, Oribatula propinqua.

3. Among oribatid mites the adults usually dominated, but Adrodamaeus femoratus, Aphelacarus acarinus, Brachychthonius impressus, Liochthonius simplex, Cosmochthonius reticulatus, Metabelba pulverulenta, and Pilogalumna crassiclava were rich in juveniles. 


\section{REFERENCES}

ArCidiacono R. 1975. Oribatei (Acarida) delle dune costiere di Gela (Sicilia) [Oribatei (Acarida) of the coastal dunes of Gela (Sicily)]. Animalia 2: 5-34 (in Italian).

Beisel J.-N., Usseglio-Polatera Ph., Bachmann V., Moreteau J.-C. 2003. A comparative analysis of evenness index sensitivity. Internat. Rev. Hydrobiol. 88: 3-15.

Berlese A. 1883. Escursione in Sicilia. Acarofauna Sicula [Excursion in Sicily. Acarofauna Sicula]. Ia serie. Bull. Soc. Entomol. Ital. 15: 212-220 (in Italian).

BerLese A. 1910. Acari nuovi. Manipulus V-VI [New mites. Manipulus VVI]. Redia 6: 199-234 (in Italian).

Bernini F., Castagnoli M., Nannelli R. 1995. Arachnida, Acari. In: Checklist of the Italian fauna species, 24. (Minelli A., Rufo S., La Posta S., Eds), pp. 1-131, Bologna, Edizioni Calderini (in Italian).

HÅgvar S., Solhøy T., Mong C. E. 2009. Primary succession of soil mites (Acari) in a Norwegian glacier foreland, with emphasis on oribatid species. Arctic, Antarct., Alpine Res. 41: 219-227.

Moraza M. L., Peña M. A. 2005a. Oribatid mites (Acari: Oribatida) in selected habitats of La Gomera (Canary Islands, Spain). Boln. Asoc. esp. Ent. 29: 39-54.

Moraza M. L., Peña M. A. 2005b. Oribatid mites (Acari: Oribatida) in selected habitats of Tenerife Island (Canary Islands, Spain). Bol. Soc. Ent. Aragonesa 1, 36: 285-291.

Odum E. P. 1971. Fundaments of ecology. W. B. Saunders Co., Georgia.

Seniczak S., Kaczmarek S., Seniczak A. 2009. Oribatid mites (Acari, Oribatida) of steppe vegetation on cape Tarhankut in Crimea (Ukraine). Biological Lett. 46: 97-103.

Seniczak S., Kaczmarek S., Seniczak A. 2011. Oribatid mites (Acari, Oribatida) of bushy stripes in steppe vegetation of cape Tarhankut in Crimea (Ukraine). Biological Lett. 48: 177-183.

Seniczak S., Kaczmarek S., Seniczak A. 2012. Oribatid mites (Acari, Oribatida) of some habitats of Korčula (Croatia). Biological Lett. 49: 279-34.

Seniczak S., Seniczak A. 2010. Oribatid mites (Acari, Oribatida) of various habitats in southern Andalusia (Spain). Biological Lett. 47: 29-35.

Seniczak S., Seniczak A. 2012. Oribatid mites (Acari, Oribatida) of selected habitats of southern Italy. Biological Lett. 49: 18-26.

Skubata P. 2000. Development of oribatid mite fauna (Acari: Oribatida) in a sedimentation tank. In: Studies on soil fauna in Central Europe (TAJovsky K., Balik V., Pizl V., Eds), pp. 177-184, ISB AR CR, Ceske Budejovice.

Skubata P. 2002. Development of oribatid mite communities (Acari, Oribatida) on a mine dump. In: Acarid Phylogeny and Evolution: Adapation in Mites and Ticks. Proceedings of the IV Symposium of the European Association of Acarologists, Siena (Bernini F., NAnnelli R., NuzZaCi G., De Lillo E., Eds), pp. 209-215, Kluwer Academic Publishers, Dordrecht - Boston - London.

Stamou G. P., Sgardelis S. P. 1989. Seasonal distribution patterns of oribatid mites (Acari: Cryptostigmata) in a forest ecosystem. J. Anim. Ecol. 58: 893-904.

SuBías L. S. 2004. Listado sistemático, sinonímico y biogeográfico de los Ácaros Oribátidos (Acariformes, Oribatida) del mundo (1758-2002) [Systematic, synonymic and biogeographical check - list of the world's oribatid mites (Acariformes, Oribatida) (1758-2002)]. Graellsia 60: 3-305 (in Spanish).

Thienemann A. 1939. Grundzüge einer allgemeinen Oecologie [Principles of general ecology]. Arch. Hydrobiol. 35: 267-285 (in German).

Weigmann G. 2006. Hornmilben (Oribatida) [Oribatid mites (Oribatida)]. In: Die Tierwelt Deutschland und der angrenzenden Meeresteile. 76. Teil (DAHL F., Ed.), pp. 1-520, Goecke \& Evers, Keltern (in German). 